\title{
Country-of-Origin Image and Its Effect on Purchase Intention: A Study on a Chinese Smartphone Brand
}

\author{
Ricky Dwi Darmawan ${ }^{1,}$ Hatane Samuel ${ }^{1,}$ Serli Wijaya ${ }^{1 *}$ \\ ${ }^{1}$ Faculty of Business and Economics, Petra Christian University, Surabaya, Indonesia \\ ${ }^{*}$ Corresponding author. Email: serliw@petra.ac.id
}

\begin{abstract}
Previous research examining the influence of country-of-origin image on purchase intention have indicated inconsistent results. China, as the largest global business players in the world have secured a lot of its brands as the world's market leaders. This research aims to examine how China, as the country of origin of Huawei smartphone, has been perceived by the Indonesian consumers. This study also aims to examine whether its country-of-origin image could influence Huawei's perceived quality, brand image, which in turn, affecting consumers' intention to purchase the product. Online survey was completed to 226 respondents using purposive sampling technique. The collected primary data was analysed using PLS-SEM technique. The findings of the study showed that, directly, country-of-origin image variable had no significant effect on purchase intention. In other words, country-of-origin image alone was not strong enough to stimulate consumers to buy the smartphone product. Research result also revealed that the role of brand image was stronger that perceived quality in mediating the effect of country of origin image on purchase intention. In fact, brand image, appeared as the significant mediating variable of how country of origin image influenced purchase intention.
\end{abstract}

Keywords: Country-of-origin image; brand image; perceived quality; purchase intention; smartphone, Huawei.

\section{INTRODUCTION}

Before deciding to buy a product, consumers will evaluate that product based on its perceived quality and brand image. According to [1], consumers use cues when forming a perception of an object which then, will influence consumer behavior towards the object. There are two kinds of cues which are, intrinsic (taste, weight) and extrinsic (price, brand, warranties, and country image). Previous research found that perceived product quality has a positive relationship to purchase intention directly. When the perceived quality of a product is getting better, it will encourage consumer's interest to buy the product [2].
Past studies have shown that country-of-origin influences consumers' purchase intention. Consumers' general assumption is that developed countries produce better quality products than developing countries [3][4]. For example, [5] found that Chinese consumers have positive attitudes toward products from the USA compared to products from newly industrialized countries such as South Korea. Similarly, [6] presented how Turkish consumers have positive perceptions regarding products from developed countries and negative perceptions with products from Russia, China, and Eastern European countries.

However, when country-of-origin is perceived poorly, it will affect both the perceived quality of a product and its brand image, which eventually influences consumers' 
purchase intention.

Within the last few decades, China has been recognized worldwide as the largest global business player next to the United States. There are lots of Chinese brands that become good market leaders, for example, in the industries of automotive, computer, and telecommunications, as well as smartphones. The smartphone industry is currently growing worldwide, and its competition is becoming more fierce to a greater extent, including in Indonesia. Additionally, with the emergence of smartphone products from China, where most of these brands penetrate the market with a cost leadership strategy and offer relatively affordable prices, it only adds more fuel to the fire.

On the other hand, among smartphone brands from China that have successfully gained their share in the Indonesian market such as Oppo, Vivo, and Xiaomi, some brands are less able to compete in the industry such as ZTE, K-Touch, Hier, Hi-Sense, and Meizu [7]. This fact indicates that having low prices does not guarantee the brand's ability to spark consumer interest in purchasing. Huawei is a globally-known smartphone brand that is currently in the second place after Samsung, which has successfully overtaken Apple as the world's second-largest smartphone seller. In 2019, Huawei won the Manufacturer of the Year Award, overthrowing Apple and Samsung. Also, the award itself was referred by competent technology journalists and a team of experts in the smartphone industry as one of the most prestigious in the smartphone industry. Yet, the interesting fact is that Huawei's performance in the global market is not in line with its sales performance in the Indonesian market [8]. Jim Xu, Huawei's Vice President for Consumer Business Group, argued that there were several reasons behind this, including the bad sales focus and a low brand image. Jim $\mathrm{Xu}$ also reasoned that during the past 4 years, Huawei had been playing at the wrong level. Many smartphone manufacturers decided not to sell any flagship products in Indonesia based on their judgment on Indonesians' average income. On the other hand, if only any smartphone vendor decides to sell their flagship smartphones, this can help to build the consumers' trust in the brand's sophisticated technology, which ultimately leads to the consumers' purchase intention. This time, Huawei used the wrong approach by playing at the entrylevel smartphone. Therefore, if Huawei keeps up with this bad strategy, it will influence their brand image and public perception that Huawei smartphones have low prices along with its qualities.

Previous researches have shown conflicting results related to the influence of country-of-origin, brand image, and perceived quality on consumers purchase intention [9-14]. For that reason, any research that explores the relationships between these four variables is deemed rather compelling. The subject analysis of this research was Huawei based on the noteworthy fact of its performance in the Indonesian market that is not in line with its success in the international market as explained in the previous section.

\section{BACKGROUND}

\subsection{Country-of-Origin Image}

The concept of country-of-origin has evolved since it was first introduced by [15], whose subject of research was business people in the USA and Japan. Nagashima defines country-of-origin as: "The picture, the reputation, the stereotype that businessmen and consumers attach to products of a specific country. This image is created by such variables as representative products, national characteristics, economic and political background, history, and traditions." [15] define country-of-origin as a stereotypical perception of a consumer regarding a country. Previous researches examining the effects of country-of-origin (COO) presented two approaches.

\subsection{Brand Image}

Describes brand image as associations toward a brand that are stored in consumers' thoughts. Similarly, [18] defines brand image as a set of associations of a brand, which is ingrained within consumers' minds that leads to the perception of that brand.

According to [19], the better the brand image of a product, the said product will gain more consumers' recognition. Generally, consumers have limited time and product knowledge before deciding to buy a product. As a result, consumers tend to make their decision through brand image [20]. Therefore, in the consumers' perspective, brand image plays a significant role in the quality of products or services [21].

\subsection{Perceived Quality}

[2] claims that perceived quality is a consumer's assessment of the overall superiority of a product. For [17], perceived quality is an evaluation of the in-process consuming experience of the overall product superiority. Additionally,[18] define perceived quality as a subjective assessment of consumers about overall superiority or overall excellence of a product.

\subsection{Purchase Intention}

Consumer purchase intention is related to the possibility of consumers' willingness to purchase a product [19]. Correspondingly, [20] also claim that consumer purchase intention is the possibility of a consumer's willingness to buy a product. The term "purchase intention" itself represents the possibilities where consumers plan to buy a product/service in the future [21]. Whenever a consumer can or intent to buy a product, purchase intention is present [22]. 


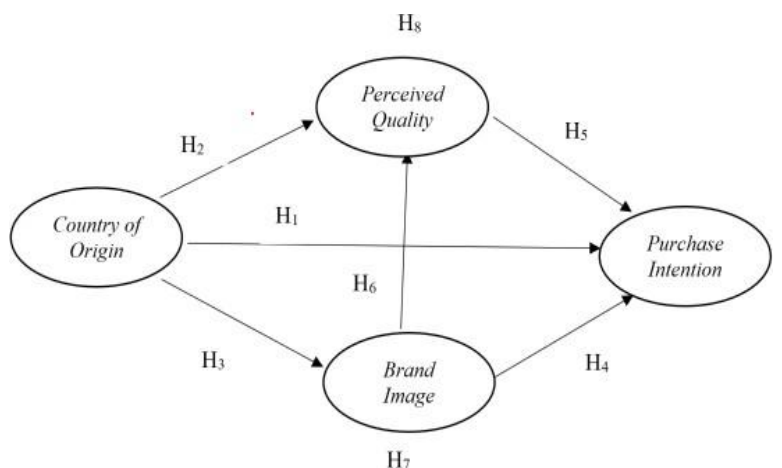

Figure 1. Proposed Conceptual Model

\section{METHODOLOGY}

This study is considered as quantitative causal type of research aiming to provide pieces of evidence or as a way of verification regarding the relationships among these four examined variables namely: country-of-origin, brand image, perceived quality, and consumer intention in purchasing Huawei smartphones.

The primary data was collected through online survey utilising Google Form design. Samples were selected applying purposive sampling technique, with sample criteria as follows: a minimum of 17 years old who reside in any cities in Indonesia, and show an intention to buy a smartphone without having any preferences regarding the brand chosen. The questionnaire was divided into 5 sections: (1) Profile of respondents section, which consists of 5 questions regarding whether respondents plan or do not plan to purchase a new smartphone soon, the smartphone brand currently owned, gender, age, average income; (2) Country-of-Origin Image section, which contains 7 questions; (3) Brand Image section consisting of 8 questions; (4) Perceived Quality section, which consists of 5 items; and (5) Purchase Intention section, which contains 4 questions.

Table 1. Convergent Validity Results

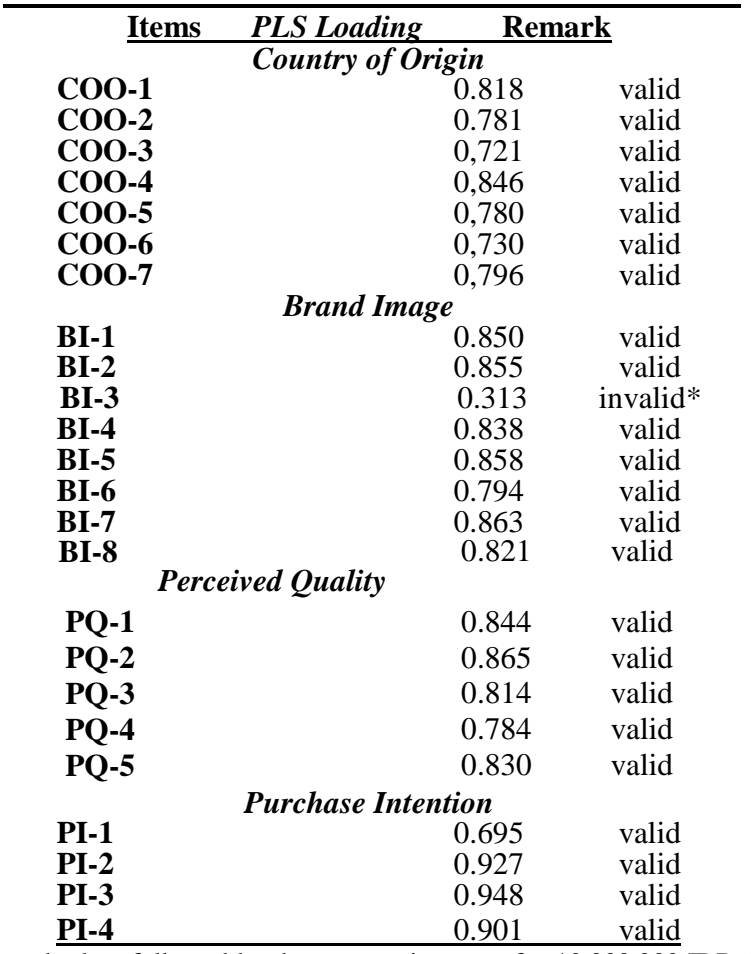

2,500,000 IDR to 4,999,999 IDR per month, then followed by the average income of > 10,000,000 IDR. Therefore, it was evident that respondents have sufficient purchasing power to buy flagship smartphones. 
Table 1 shows the convergent validity with the outer loading value of each indicator. If an indicator has an outer loading value greater than 0.5 , then it is valid as it meets the convergent validity requirement. As shown in Table 1, item BI-3 has an outer loading of 0.313; Therefore, in the following analysis, the role of this indicator would be diminished. Table 2 discusses discriminant validity where the Average Variance Extracted (AVE) for the Country-of- Origin Image variable is 0.613 , the AVE for the Brand Image variable is 0.706 , the AVE for the Perceived Quality variable is 0.686, and the AVE for the Purchase Intention variable is 0.661 . Consequently, each variable has its loading value above 0.5 , so it confirms that each variable is valid. Hence, considering the result meets the predetermined requirements to be above 0.5 , it is emphasized that the model had good discriminant validity. Additionally, the structural model of the examined four variables meets the ideal standard of composite reliability since each variable (Country-of-Origin Image, Brand Image, Perceived Quality, and Purchase Intention) has a composite reliability score greater than 0.7 .

Table 2 also reports high scores of Cronbach's alpha value of each variable with more than $\geq 0.6$ (the Countryof- Origin Image variable is 0.917 , the Brand Image variable is 0.944 , the Perceived Quality variable is 0.916 , the Purchase Intention variable is 0.927), therefore, all variables are deemed reliable since they meet the minimum value requirements.

Table 2 Discriminant Validity Result

Variable Composite AVE Cronbach's

$\begin{array}{llll}\text { Purchase Intention } & 0.764 & 0.661 & 0.927\end{array}$ 4=Agree; and 5=Strongly Agree.

\section{RESULTS}

A total of 230 participants participated in the online survey. However, after conducting data screening, only 226 out of 230 questionnaires were valid for the next step in data processing. The respondents consisted of 116 men and 110 women. Through 226 samples, 38 respondents answered that they had a smartphone purchase plan shortly, 88 respondents decided to leave it open by answering that it was possible, and the rest 100 respondents answered that they did not have a plan to buy a new smartphone. The three most owned smartphone brands were Samsung, Apple, Oppo, followed by Xiaomi, and Vivo. The questionnaire data also reported that most of the respondents came from the age of 18-30 years old, with the majority working as private employees. Correspondingly, the questionnaire stated that most respondents had an income of around

\section{DISCUSSION AND CONCLUSIONS}

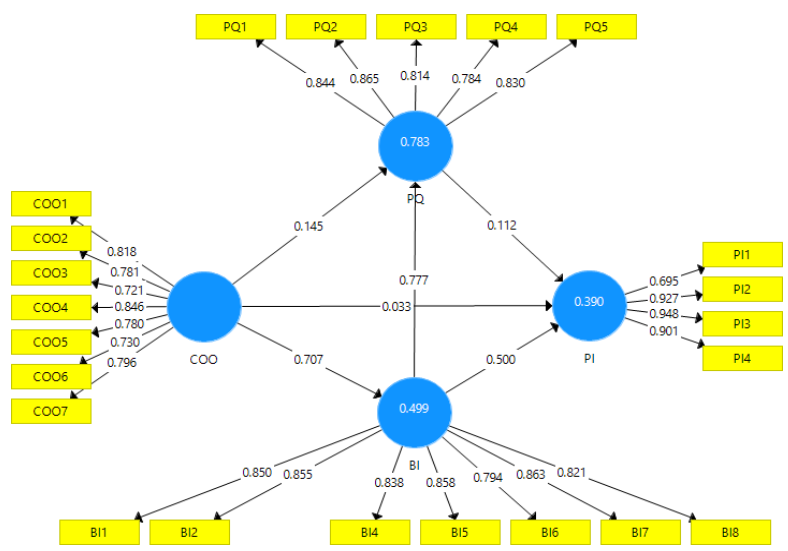

Figure 2 SEM-PLS Bootstrapping Result

Figure 2 shows the results of the bootstrapping from the structural model used in this research. 
Table 3 Hypotheses Result

\begin{tabular}{llrrrrl}
\hline Hipotesis & Variabel & $\begin{array}{c}\text { Original } \\
\text { Sample } \\
\text { Estimate }\end{array}$ & $\begin{array}{c}\text { Sample } \\
\text { Mean }\end{array}$ & $\begin{array}{c}\text { Standard } \\
\text { Deviation }\end{array}$ & $\begin{array}{c}T- \\
\text { Statistic }\end{array}$ & $\begin{array}{l}\text { Keputusan } \\
\text { Pengujian } \\
\text { Hipotesis }\end{array}$ \\
\hline H1 & COO-PI & 0,033 & 0,031 & 0,070 & 0,474 & Ditolak \\
H2 & COO-PQ & 0,145 & 0,145 & 0,045 & 3,208 & Diterima \\
H3 & COO-BI & 0,707 & 0,706 & 0,038 & 18,683 & Diterima \\
H4 & BI-PI & 0,500 & 0,507 & 0,130 & 3,852 & Diterima \\
H5 & PQ-PI & 0,112 & 0,109 & 0,133 & 0,845 & Ditolak \\
H6 & BI-PQ & 0,777 & 0,775 & 0,042 & 18,291 & Diterima \\
H7 & COO-BI-PI & 0,353 & 0,358 & 0,096 & 3,698 & Diterima \\
H8 & COO-PQ-PI & 0,016 & 0,015 & 0,020 & 0,814 & Ditolak \\
\hline
\end{tabular}

Table 3 illustrates the results of hypotheses testing. The results show that five out of eight hypotheses were accepted. H1 (t-statistics $=0.474), \mathrm{H} 5$ (t-statistics = $0.845)$, and $\mathrm{H} 8$ ( $\mathrm{t}-$ statistics $=0.814$ ) were rejected because each of its t- statistic values was less than 1.96 in the t-table.

The results showed that the country-of-origin image had no direct relationship with consumers' purchase intention. Although respondents had a fairly positive perception of China as Huawei's country-of-origin, it did not necessarily play a role in the consumers' purchase intention. On the other hand, the results also indicated that emotional or psychological factors, for example, selfcongruity, played a more significant role in encouraging respondents' intention to buy a product. Moreover, according to Maslow's hierarchy of needs, smartphone products are deemed to satisfy consumers' social needs and their self-esteem. Hence, one out of many reasons for a consumer to buy a new smartphone could be just a mere hedonic impetus of prestige in addition to its utilitarian values. This fact then led to the argument of why the country-of-origin image itself is not strong enough to influence consumers' purchase intention. For this reason, it was important for other variables to come into play in influencing consumers' purchase intention.

The findings of this study also shown that the countryof- origin image variable had a direct relationship with the perceived quality variable. Respondents claimed that China's manufacturing quality is low that it affected the perceived quality of Huawei's smartphones. Therefore, having China as Huawei's country-of-origin, consumers assumed Huawei's smartphones to be lacking in features and have a low level of durability. Furthermore, the country-of-origin image variable also influenced the brand image variable directly. Since respondents had the perception that China manufactures low-quality smartphones, it caused them to have an ingrained set of associations related to Huawei which resulted in Huawei being taken into account a bit less in the market compared to its more expensive smartphones competitors. Ultimately, this led respondents to perceive Huawei's quality rather negatively.

Brand image could affect purchase intention in one way or another in a slightly significant manner. As mentioned earlier that respondents had the perception that China manufactures low-quality smartphones, it caused them to have an ingrained set of associations related to Huawei which resulted in Huawei being taken into account a bit less in the market compared to its more expensive smartphones competitors. If respondents perceive Huawei's quality rather negatively, they will have zero or little intention to purchase a Huawei smartphone.

The perceived quality variable had no direct influence to the purchase intention variable. This happened due to the perceived quality created by Huawei that had not been able to encourage respondents to make purchases. The results of this research also indicated that emotional or psychological factors, for example, self-congruity, played a more significant role in encouraging respondents' intention to purchase a product. Moving on, it is showed that the brand image variable influences the perceived quality variable rather directly. It was evident that from respondents' perception, Huawei is being taken into account a bit less in the market compared to its more expensive smartphone competitors.

Interestingly, by putting the brand image as a mediating variable between the country-of-origin image and the purchase intention variable, this affirmed that the two variables significantly affected one another. The reason behind this was the negative perception that the respondents had towards China, Huawei's country-oforigin, which led to the assumption that Huawei's smartphones are lacking in features and possess a low level of durability, which eventually contributed to the consumers' intention not to purchase Huawei smartphones.

In contrast, by putting the perceived quality as a mediating variable between the country-of-origin image and the purchase intention variable, this claimed that the two variables did not influence one another. Despite the fact that the respondents were well-aware that China is a developed or industrialized country, this did not necessarily create a positive perceived quality towards Huawei that encouraged respondents to buy a Huawei smartphone. 


\section{CONCLUSION AND RECOMMENDATION}

As a manufacturer, Huawei needs to establish the image of China as a developed country through its product marketing and advertisement programs because the majority of respondents strongly relate and agree to that. Also, Huawei shall invest more time in socializing its new European- themed campus, namely Huawei Ox Horn Campus, in Dongguan, with an area of $9 \mathrm{~km}^{2}$ or 900 hectares, which replicates 12 major cities in Europe. These 12 sections function as offices, factories, R\&D facilities, and residences for 25,000 Huawei employees. The campus also has its dedicated commuter train to travel around the campus.

Next, Huawei also needs to introduce its sophistication or technological advancement in the process of making their smartphones in every marketing mix, advertisement, and promotion in front of potential customers. This aims to change the perception of how China products are equal to low-quality products in terms of product manufacturing that is attached to consumers' thoughts, and so that consumers can finally understand sophisticated aspects of the Huawei smartphone itself.

Importantly, Huawei should enhance or add more features on their smartphones that are still lacking from the consumers' perspectives. One of the urgent matters to be taken care of is to find a replacement for the Google Play Store which can no longer be used or accessed on the most recent Huawei's smartphones. Also, it will be better if Huawei upgrades the durability level of their smartphones, so they get more rugged and more durable. To anticipate this matter, play or show videos of Huawei's smartphones durability test to consumers since respondents still have a perception that the durability level of Huawei smartphones is low. Additionally, Huawei needs to improve its competitiveness in the smartphone industry, especially in Indonesia, because respondents stated that Huawei's quality is being taken into account a bit less in the market. One of the best possible solutions, for the time being, is to provide easier access to Huawei smartphone products through large and well-known retail stores.

Since respondents consider that the price range of Huawei's competitors is still more expensive, Huawei also needs to adjust the pricing strategy of its smartphones to establish premium impressions in the perspectives of consumers.

For future researches, the authors strongly suggest to pay more attention to the sampling technique. Given the limitations of the study, the conducted sampling technique was carried out through online fashion, resulting in the authors' very limited ability to control distribution and respondents. Moreover, it is optional but highly appreciated to elaborate more details in the respondents' profile section regarding education level, frequency of traveling abroad, or visiting China. The last suggestion for future researches is to include more variables such as consumer ethnocentrism, country familiarity, price, self-congruity, and prestige.

\section{REFERENCES}

[1] Z.U., Ahmed et al., "Country-of-origin and brand effects on consumers' evaluations of cruise lines," Intl. Marketing Review, vol. 19, no. 3, pp. 279302, 2002.

[2] R. Tsiotsou, "The role of perceived product quality and overall satisfaction on purchase intentions," Intl. J. of Consumer Studies, vol. 30, no.2, pp. 207-217, 2006.

[3] K. Kurtuluş and Z. Bozbay, "Comparing country images of Japan and China,". İstanbul Üniversitesi Işletme Fakültesi Dergisi, vol.40, no. 2, pp. 267277, 2011.

[4] C.L. Wang et al. "Country image, product image and consumer purchase intention: Evidence from an emerging economy,". Intl. Business Review, vol. 21, no. 6, pp. 1041- 1051. 2012.

[5] S. Ahmed and A. D'Astous, "Perceptions of countries as producers of consumer goods: A Tshirt study in China," J. of Fashion Marketing and Management, vol. 8, no. 2, 187-200, 2004.

[6] E. Kaynak and A. Kara, "Consumer perceptions of foreign products," European J. of Marketing, vol. 36, no. 7/8, pp. 928-949. 2002.

[7] S. Audita, S, "Lima Merek HP China yang Gagal dan Gak Laku di Indonesia | Gara-Gara Xiaomi?" diakses dari https://jalantikus.com/gadgets/merekhp-china-yang-kini- bangkrut/ [tanggal akses 14 October 2019].

[8] D. Irvan, D, "Huawei Meminta Maaf kepada Konsumen Indonesia," diakses dari https://gadget.jagatreview.com/2018/07/huaweimeminta-maaf-kepadakonsumen-indonesia/ [tanggal akses 30 September 2019].

[9] J. Dinata et al. (2015). Country of origin dan pengaruhnya terhadap persepsi kualitas dan minat beli: Survei pada Calon Konsumen yang Berminat Membeli iPad di Indonesia). Jurnal Administrasi Bisnis, vol. 25, no. 1, pp. 1-8, 2015.

[10] M. Permana, M and J. Haryanto, "Country of origin, brand image,". J. Manajemen, vol. 18, no. 3, pp. 365-380. 2014.

[11] K.P. Yanthi and Jatra, I.M. (2015). Pengaruh country of origin, brand image, dan perceived quality terhadap minat beli sepeda motor Honda Beat di kota Denpasar. vol. 4, no. 1, 3852-3881.

[12] S. S. Bhakar et al, "Relationship between country of origin, brand image and customer purchase 
intentions, " Far East Journal of Psychology and Business, vol. 11, no. 1, pp. 50-71., 2013.

[13] V. Rafida, "Pengaruh Country Of Origin terhadap Minat Beli dengan Perceived Quality Sebagai Variabel Intervening (Studi pada Pengunjung Artomorro Selluler Kota Madiun)," Jurnal Pendidikan Tata Niaga (JPTN), vol., no. 2. 2005.

[14] Wahyutati, P., Suharyono, \& Yulianto, E. (2015). Pengaruh country of origin dan global brand image terhadap minat beli dan keputusan pembelian (Survei pada Konsumen yang Membeli Smartphone Samsung Galaxy di Asia Tenggara). Jurnal Administrasi Bisnis, vol. 25, no. 1, pp. 110., 2015.

[15] A. Nagashima. A Comparative "Made In" Product Image Survey Among Japanese Businessmen. J. of Marketing, vol. 41, no. 3, pp. 95-100. 1997.

[16] Roth, M. S., \& Romeo, J. B. (1992). Matching Product Category and Country Image Perceptions: A Framework for Managing Country-of-Origin Effects. J. of International Business Studies, vol. 23, no. 3, pp. 477-497.

[17] D. Aaker. "Managing Brand Equity: Capitalizing on the Value of a Brand Name. Free Press. 1991.

[18] Keller, L. K.. Conceptualizing, measuring and managing customer based brand equity. Journal of Marketing, vol. 57, pp. 1-22, 1993.

[19] Grewal, D., Krishnan, R., Baker, J., \& Borin, N. The effect of store name, brand name and price discounts on consumers' evaluations and purchase intentions. Journal of Retailing, vol. 74, no. 3, pp.
331-352. 1998.

[20] P.S. Richardson et al. Extrinsic and Intrinsic Cue Effects on Perceptions of Store Brand Quality. J. of Marketing, vol. 58, no. 4, pp. 28-36. 1994.

[21] M.E. Salinas and J.M.P., Perez, J. M. P. "Modelling the brand extensions' influence on brand image," J. of Business Research, vo. 62, no. 1, pp. 50-60. 2009.

[22] D.A. Baker and J.L. Crompton, "Quality, satisfaction and behavioral intentions," Annals of Tourism Research, vol. 27, no. 3, pp. 785-804. 2011.

[23] V.A. Zeithaml et al. "The Behavioral Consequences of Service Quality." Journal of Marketing, vol. 3 no. 2. pp. 341-396. 1996.

[24] W.B. Dodds et al, Effects of Price, Brand, and Store Information on Buyers' Product Evaluations," J. of Marketing Research, vol. 28, no. 3, pp. 307-319. 2011.

[25] K. Shirin and H.H. Kambiz, "The Effect of the Country-of-Origin Image, Product Knowledge and Product Involvement on Consumer Purchase Decisions,". Chinese Business Review, vol. 10, no. 08, pp. 601-615. 2011.

[26] L. Schiffman and L. Kanuk, L. "Consumer Behavior, (9 ed.). Pearson. 2010.

[27] V.G. Morwitz and D. Schmittlein, Using Segmentation to Improve Sales Forecasts Based on Purchase Intent: Which "Intenders" Actually Buy? J. of Marketing Research, vol. 29, no. 4, pp. 391. 1992. 